\title{
Some Aspects of the Relationship between Talent Management and Service Quality Components in Egyptian Law Firms
}

\author{
Suzana Košir \\ American University of Middle East, Kuwait \\ suzana.kosir@gmail.com
}

Radhika Lakshminarayanan

American University of Middle East, Kuwait

radhika.laxman@aum.edu.kw

\author{
Dina Sabry Said \\ American University of Middle East, Kuwait \\ dina.said@aum.edu.kw
}

\begin{abstract}
Purpose: The purpose of this study is to show that talent management (TM) is an influential tool for law firms to gain a competitive advantage, develop competencies and sustain service quality (SQ), which is crucial to their success.

Study design/methodology/approach: A quantitative non-experimental research method was used to evaluate the relationship between TM and SQ components in law firms, focusing on a designed model of correlations to explore some aspects of the relationship between TM and SQ components.

Findings: The findings from correlation and multiple regression analysis show that not all the selected components of TM have a significant relationship with the SQ components. In the study, performance management and compensation components of TM indicate a low correlation with SQ components. Ongoing performance, assessment and concurrent training programs also serve to improve SQ and enhance the overall effectiveness of TM. Study shows that law firms need to develop strategies and constantly compile data on employees and job positions for consistent TM and development.

Originality/value: The study evaluates a vital aspect of the linkages between TM and SQ components. It suggests ways of improving program effectiveness, employees' overall performance, and retention of the best talent in legal organisations.
\end{abstract}

Keywords: talent management, service quality, law firm, organisational behaviour

\section{Introduction}

Human resource managers face inherent challenges in talent acquisition, diversity inclusion, compensation, and creating an organisational ethos where every employee feels valued and committed. Talent acquisition relates to attracting and retaining top talent in the industry, which in turn affects the organisation's long-term success. In Egypt, particularly after the 2011 revolution due to increased susceptibility to international claims before the International Centre for Settlement of Investment Disputes (ICSID) (Taha, 2014), there was a proliferation of arbitration law firms, with each law firm aggressively competing to attract the best talent. Law firms use proactive and innovative recruiting strategies by creating a pipeline between legal education and law practice to ensure that prospective employees are adequately trained to take on the opportunities and challenges in legal practice. Law firms compete with each other and organisations because they are all seeking to recruit top talented incumbents (Brown et al., 2004; Stangl, 2008). Without effective strategies, law firms will face risks of increased attrition and remain unable to attract the required talent to maintain their standard in a competitive global marketplace.

One of the vital human resource strategies is effective Talent Management (TM), which seeks to identify, deploy and retain professionals that are both talented and with high-performance expectations. TM needs to remain a strategic priority for law firms for their present survival 
and future success. Law firms remain hindered by shortages of skillsets, increased diversity among clients in varied demographies, and emerging conviction of more outstanding work-life balance among prospective employees, which further augments the competition as the right talent can make a considerable difference to the firm's performance.

Talent is broadly defined as the total of a person's ability, including their skills, knowledge and potential for development. Ultimately, the organisation seeks to determine which employee can be defined as 'high potential'. (Blass, 2007). With the advent of the concept of TM, HR departments focus on broader realities such as

- To determine an effective and efficient recruitment process

- To mentor and develop managers and leaders by reinforcing organisational culture, instilling core values, and creating a sustainable "leadership pipeline".

- To identify competency gaps and deliver training, e-learning and development workshops to fill these gaps.

- To identify high performers and potential successors to key positions

TM has been well defined as "the implementation of integrated strategies or systems designed to increase workplace productivity by developing improved processes for attracting, developing, retaining and utilising people with the required skills and aptitude to meet current and future business needs". (Oehley, 2007, p. 43)

This suggests that the process of TM needs frequent and sustained development, adjustment and transformation to ensure that the process remains aligned with organisational strategies and goals. It is a continuous process rather than an intervention of limited duration. An organisation's strategic perspective shapes how an appropriate TM system is developed and implemented.

Although TM might be applied in law firms, optimal contribution and success are only possible if top management and employees align with its objectives and implementation in the organisation. In many cases, there is a misalignment between the perception of legal employees and the management, particularly on competency models, communication and compensation. Hiring and retaining talented legal employees is costly due to high compensation packages and the time and effort allocated to their training and development. However, it is often noted that consistently motivating talented employees towards optimal performance is a challenge that many law firms face, impacting the overall quality of service.

Service Quality (SQ) is reflected in providing outstanding service to clients, such that clients do not hesitate to use the firm's services again and even refer the firm to others as well. From a customer viewpoint, SQ translates as a service that best corresponds to client expectations and satisfies the client's needs and requirements (Enquist et al., 2007). If the service offered does not match expectations, clients would be less likely to seek the firm's service, mainly since there are unlimited options with competitors flooding the market.

This research studies the interrelation between TM and SQ within the above context, intending to determine the impact of TM components on SQ. The research problem seeks to respond to the following queries:

1. To determine the significance of TM in the workplace and its significant components and challenges that impact workplace success.

2. To determine the significance of SQ in the workplace and its significant components and challenges that impact workplace success.

3. To determine the correlation between vital components of TM and their relationship with SQ components in the workplace. 
There is a vital need for such a study mainly because law firms need to search and recruit the best talent with the required skills and provide these new recruits with the appropriate training and mentorship programs. Secondly, law firms need to identify suitable ways of rewarding staff for quality performance if they aspire to acquire and retain the best talent in the industry. Thirdly, by identifying factors that increase the motivation and commitment level of the staff, HR managers can support their employees through effective policies and strategies that would impact the workplace culture and success. To the authors' best knowledge, there has not been any previous attempt to address the impact of TM on SQ in law firms in Egypt. However, numerous law firms in Egypt operate with a diverse workforce selected from across the globe, which provided for a rare study on TM.

Deriving from the above, the main objective of this study is to evaluate some valuable aspects of the impact of TM components on service quality (SQ) components in arbitration law firms in Egypt while focusing on the correlation between them. The paper has been structured to provide an initial contextual definition of TM and its core components and the challenges facing effective implementation of TM. Further, the definitions of SQ are analysed within context, and the viability of the SERVQUAL components approach is evaluated. Section 2 provides the research background and reviews existing literature on the subject. Section 3 and 4 discuss the research model and hypotheses development and methodology. A quantitative nonexperimental research method was used to evaluate the impact of TM components on SQ components, focusing on a designed model of correlations. Finally, the linkages between TM components and SQ components are presented, and other ways of improving program effectiveness, employees' overall performance, and retention of the best talent in legal organisations are recommended.

\section{Talent Management}

Talent management (TM) is a holistic approach to human resource planning and management for organisational competence through the use of human resource (HR) interventions (Brown et al., 2004; Collings \& Mellahi, 2009; Lewis \& Heckman, 2006). It involves aligning the organisational strategy with the skills and talents of its employees by providing 'the right person, with the right role, with the right tools' (Dhanabhakyam \& Kokilambal, 2014).

The concept of TM initially focused on recruitment and gradually evolved to a broader concept aimed at attracting, retaining, and developing talented employees (D'Annunzio-Green, 2008). TM requires a systematic focus on the performance of employees, supplemented through rigorous skill training, building career paths and utilising knowledge (Lopes, 2016) to enhance the organisational growth and mission.

Most literature relating to the legal profession has consistently stressed the importance of human talent to the success of law firms (Mayson, 2007). It is widely believed that high performers contribute toward better service quality and enhance law firm reputation and growth (Galanter \& Palay, 1990; Gilson \& Mnookin, 1989). The importance of TM stems from the shared belief that HR is the organisation's primary source of competitive advantage and a vital asset for organisational success and survival (Uren, 2007).

Effective TM could also ensure justice and fairness among employees, which would promote cohesion and harmony, rather than creating rift and suspicion by differentiating in terms of standardised performance expectations (Zhang et al., 2020). TM is a multi-faceted concept championed by HR practitioners, fuelled by the war for talent and built on the foundations of strategic human resource management (HRM). Effective TM ensures that organisations can successfully acquire and retain essential talent and engage them to their best competencies. The ability to effectively address both of these issues has become a primary determinant of 
organisational success and, in some cases, even survival (Christensen Hughes \& Rog, 2008). $\mathrm{TM}$ is therefore defined as both a philosophy and practice, both an espoused and enacted commitment shared at the highest levels and throughout the organisation by all managerial and supervisory positions to implement an integrated, strategic and technology-enabled approach to HRM particular focus on human resource planning.

\section{Components of Talent Management}

TM components presented by Mehta (2011)are essential to maximising performance for the organisation. They include the following: 1) Strategic employment planning, 2) Talent acquisition and retention, 3) Performance management, 4) Career development, and 5) Succession Planning. Analysing different literature, we found two additional components which were interesting to add to this study. Moore (2013) also mentioned 6) Learning and motivating and 7) Compensation components. These other components were also measured for this study.

1. Strategic Employee Planning: The organisation must identify key job roles and the required employees to fulfil those roles by forecasting talent needs and creating competency profiles for lawyers, support staff, and other professionals (Dhanabhakyam \& Kokilambal 2014).

2. Talent Acquisition and Retention: The critical activity of TM is discerning, recognising and nurturing talent relative to organisational requirements. This should be adapted to lawyers with a profile of working with different professionals instead of focusing solely on a single client profile. Retaining current employees through intrinsic training programs, investing in enhanced internal processes and infrastructure helps build individual capacities (Järvi \& Khoreva, 2020) and ultimately serve the organisational interests. Total talent acquisition validates that anyone working within the organisation is considered talent and incorporated (at least to some degree) in TM, recognising that such integration is crucial (Mehta, 2011).

3. Performance Management: Employee Performance management includes communicating transparently and clearly with employees about organisational expectations and measuring their progress based on smart goals by focusing on strengths, not only weaknesses (Harter \& Adkins, 2015). Linking performance with the rewards system also serves to build employee motivation (Lavanya \& Sumathi, 2019). The manager's role should provide the employees with the opportunity to learn more about their career field and strive to reward the employees who perform as per expectations (Govaerts et al., 2011). Performance management ensures that organisational goals are met and facilitates meaningful communication, promoting higher retention and morale within the organisation (Mehta, 2011).

4. Career Development: Another vital element in TM is identifying and developing future organisational leaders. This involves providing specialised development tools to prepare them for leadership positions (Irtaimeh \& Al-Azzam, 2016). For example, effective mentoring programs and job rotations can be powerful tools for career development and meaningful assignments that fulfil employee needs (Stahl et al., 2012).

5. Succession Planning: A vital component in TM, Succession Planning helps in effectively filling key positions with appropriate talent (Santhanalaxmi \& Chandramohan, 2019). Having a succession plan ensures that the organisation will run smoothly if and when a key position needs to be filled quickly (Trigunait \& Taruna, 2020). Serious TM advocates the need for the proactive identification of key people in the organisation and developing a plan to manage people and positions. Employing technology solutions can further facilitate this process and will mitigate obstacles. Such a TM program would also optimise organisational performance (Mehta, 2011). 
6. Learning and Motivating: By implementing learning programs that can enhance the acquisition of information and skills through formal and informal learning, both knowledge and experience can be enhanced. (Dhanabhakyam \& Kokilambal, 2014). In addition, recognising employees' commitment and hard work, providing them with rewards and incentives as an acknowledgement of their value to the organisation contributes to increasing staff morale and decreasing the attrition rate (Nithyapriya \& Balaji, 2019).

7. Compensation: To retain top talent, a competitive compensation package is essential, but companies also need to recognise that financial incentives form only one element of success (D'Annunzio-Green \& Ramdhony, 2019), as this would not be the only consideration when prospective employees choose a job or existing ones decide to continue existing jobs (Chaubey \& Gupta, 2013). Other elements include providing employees with exciting assignments and a choice of job tasks, which could be more significant motivators than financial rewards (Prowse \& Prowse, 2009). In addition, providing employees with opportunities to choose job-related tasks related to their experience, motivation, personal and professional goals (Sanchez \& Levine, 2012) also impacts job satisfaction and organisational commitment and turnover and stress levels (Holtom et al., 2008).

\section{Challenges facing effective TM}

Effective TM can make organisations stand out from competitors and reach excellence in the industry. However, TM involves many challenges to this:

1. The search for top talent is a continuous and expensive process as the demand for talented employees is constantly increasing, even as supply decreases (Beechler \& Woodward, 2009). The ALPMA/Rusher Rogers Legal Industry Salary and HR Issues Survey Report (The ALPMA-Annual Report 2014-2015, 2015) states that finding good people remains the most significant HR challenge for law firms. As a result, talent acquisition has become a severe concern for law firms, especially when internationalising into other markets (Suseno \& Pinnington, 2017).

2. Many legal professionals seek international exposure through work opportunities in different countries to develop their skills, knowledge, and broader experience (Suseno \& Pinnington, 2017).

3. Having a strong organisational brand based on long experiences, legacy, and reputation is a valuable criterion in attracting talented potential applicants (Gioia et al., 2000). This signifies that organisations should invest considerable time and resources to build and sustain a global brand.

4. While previously employees with the most extended work experience were nominated for leadership roles, in recent times, it is recognised that leadership competencies include systematic thinking, social skills, behavioural competencies and emotional intelligence (Groysberg \& Abrahams, 2006).

5. Traditional managers usually prioritise current employee performance over longer-term talent development (Whysall et al., 2019). They fail to realise that satisfactory delivery of work in the short term is as important as developing employees' capabilities for the future. As clients would benefit from professional talent all the way along (Baldassari \& Roux, 2017), there is a need to constantly build talent to meet future challenges (Lavanya \& Sumathi, 2019) while at the same time addressing current requirements. 


\section{Service Quality}

Although Service Quality (SQ) has received attention from academic researchers in the last two decades, it has no clear definition, nor is there a clear understanding of its components or measurement. Most of the definitions focus on meeting customer needs and requirements (Elseidi, 2009). It is defined as measuring how well the service delivered matches customer expectations (Elseleety, 2004). It refers to client perceptions and expectations of the quality of services by comparing the gap between their expectations of what the service company should offer and their perception of the companies' service performance from the actual service performance (Shehata, 2006). Owing to the abstract nature of the concept of SQ and the characteristics of the service, measuring SQ is a complicated task (Carman, 1990; Parasuraman et al., 1988).

Parasuraman et al. (1988) proposed a well-known framework for measuring service quality, the SERVQUAL scale, which has been used in various sectors. The original SERVQUAL comprised of ten determinant service components, derived through extensive statistical analysis in 1988. After identifying significant correlations between several of the components, the ten service components collapsed into five, which are: 1) Tangibles (physical facilities, the appearance of personnel, tools used to perform the service and other customers in the service facility); 2) Reliability (the ability to provide consistent performance and provide the promised service accurately and dependably); 3) Responsiveness (employees' readiness to deliver the service and to give prompt service); 4) Assurance (employees' knowledge to perform the service, employees' politeness, respect and consideration, and their ability to inspire trust and confidence) and 5) Empathy (caring, understanding customers' needs and paying attention, individually, to the customers). The SERVQUAL model (Almomani, 2017) is a valuable tool for understanding the notion of SQ, as defined by the customer and allows researchers to measure the gap between customers' expectations of service and their perceived service experiences (Ramseook-Munhurrun et al., 2010).

Six key themes emerged in defining 'good service quality in the Legal profession (Quality in Legal Services, 2010). They can be enumerated as follows; 1) empathy (clients feel that they are a priority); 2) efficient processes (attention should be given to efficient work processes towards ensuring consistent progress); 3) outcomes (the more the cases being settled promptly, the better the quality of service as perceived by clients); 4) professional presentation (visual presentation and a professional appearance related to the legal firm and the legal professional); 5) clarity and de-mystification and 6) proactively using their knowledge (leveraging or communicating existing knowledge).

More law departments realise the value of soliciting client feedback in many areas, including work product, timeliness/responsiveness, overall service attitude and staffing of the law department through client surveys. Once assured of confidentiality, clients are generally open, constructive and candid. In addition, they are often cooperative, constructive and sincerely interested in improving the complex relationship between the law department and the business units (Altman \& Weil, 2007). Therefore, there is a vital need to concentrate on all five SERVQUAL components in order of importance (Arlen \& Talley, 2008) to ensure the high quality of the service provided.

\section{Methodology}

\section{Objectives and hypothesis}

The present study evaluates some aspects of the impact of TM components on SQ components in arbitration law firms in Egypt while focusing on the correlation between them, based on the 
assumption that there is a correlation. The research population included the law firms located in Greater Cairo and working in the arena of International Arbitration and Dispute Resolution. However, small-sized organisations with less than 50 employees were excluded due to their dispersion geographically and might not represent the research population.

The research methodology used in this study was a quantitative non-experimental method which included the questionnaire used to understand the correlation of TM components and SQ components on arbitration law firms in Egypt. The study's main objective was to identify correlations, links, and gaps between the components of TM and SQ components based on the designed model (Figure 1). Based on the literature review and the research objectives, the following hypothesis was formulated:

Hypothesis: There is a significant relationship between all TM and all SQ components.

TALENT MANAGEMENT

Strategic employment planning
Talent acquisition and retention
Cerformance management
Career development
Succession planning

Legend:

$\longrightarrow$ Strong correlation

Figure 1: Expected impact of TM components on SQ components

\section{Data collection and sample}

Based on the research questions, a form of correlation research was used. The researcher measures the two variables of interest with little or no attempt to control extraneous variables and then assesses their relationship (Chiang et al., 2015). Correlation research provides a realistic view of the questions we are researching because we do not influence what happens. Furthermore, the measures of the variables are not biased by the researcher (Field, 2009).

In the present study, the selection criteria were the leading arbitration law firms in Egypt, whose associates and business service staff had to answer a series of questions and statements regarding the implication of TM and SQ in their organisations. In the study, a non-probability, purposive or selective sampling method (Singh, 2007) was used. Thus, the researcher relies on his or her judgement when choosing members of the population included in the study. In this method, homogeneous sampling was used, which enabled a focus on a particular subgroup where all the sample members are similar or based on knowledge of the population, its elements, and the study's purpose (Babbie, 2008).

In the present survey (Table 1), 256 questionnaires were distributed among associates and business service staff in eight leading arbitration law firms in Egypt. 206 questionnaires were resolved and returned, which showed a high response rate of $80.4 \%$. The sample presented 131 
$(64 \%)$ of the female population and $75(36 \%)$ of the male population. The most significant number of respondents was $122(59 \%)$ who were between 30 and 40 years of age, while 49 (24\%) respondents were less than 30 years and $35(17 \%)$ were more than 40 years old. Based on the job type, $128(62 \%)$ of respondents were business service staff, $51(25 \%)$ were lawyers, and $27(13 \%)$ were senior lawyers. Based on experience, $142(69 \%)$ respondents had more than 6 years of work experience, 37 (18\%) respondents had between 3-6 years of work experience, and $27(13 \%)$ respondents had less than 3 years of work experience.

Table 1: Socio demographical data

\begin{tabular}{|l|l|l|}
\hline Gender & Frequency & Per cent \\
\hline Male & 75 & $36 \%$ \\
\hline Female & 131 & $64 \%$ \\
\hline Age & & \\
\hline Less than 30 & 49 & $24 \%$ \\
\hline $30-40$ & 122 & $59 \%$ \\
\hline More than 40 & 35 & $17 \%$ \\
\hline Job type & & \\
\hline Senior Lawyers & 27 & $13 \%$ \\
\hline Lawyers & 51 & $25 \%$ \\
\hline Business Services Staff & 128 & $62 \%$ \\
\hline Experience & & \\
\hline Less than 3 years & 27 & $13 \%$ \\
\hline 3-6 years & 37 & $18 \%$ \\
\hline More than 6 years & 142 & $69 \%$ \\
\hline
\end{tabular}

\section{Survey}

The survey was divided into two parts. The first part was focused on seven primary areas or TM components and the second part focused on the five components of SQ based on the SERVQUAL model. Respondents were asked to rate the responses in nominal and ordinal scales. The five-point Likert scale was used (absolutely disagree, disagree, neither disagree nor agree, agree and absolutely agree) (Bryman, 2012), which indicated the level of agreement or disagreement with the statement.

The first part of the questionnaire aimed at examining the seven components of TM.

1. The first component measured was Strategic Employment Planning, which included importance placed by the organisation in retaining highly qualified employees, prioritisation of employees development, recognising exceptional performance, and understanding personal and family need.

2. The second component measured was Talent Acquisition and Retention in organisations through overall organisational knowledge of recruitment process and policies, appointing high-quality employees, and filling a vacancy in a short time.

3. The third component measured was Performance Management, such as the level of appropriate performance of a team member, performance problems and their prompt solutions, the employee's performance during the appraisal process, the adjustment of managerial discussion, and action-based employee performance.

4. The fourth component measured was Learning and Motivating. It included the genuine interest of the organisation to foster the learning and development of employees, coaching staff one-on-on, active creation of development opportunities for subordinates, and efforts at meeting with team members for formal career planning. 
5. The fifth component measured was Compensation, based on whether the organisation provides verbal or written communication for individual contribution, allocates salary increases fairly and according to individual performance, ensures that salaries are market-related and celebrates the exceptional performance of employees.

6. The sixth component measured was Career Development, based on whether the organisations implement discussion of a clear future and encourages toward a vision, ensures team members link their individual contribution to the strategic objectives, creates opportunities for team members to participate in challenging assignments and make decisions when appropriate and equips team members with the necessary information and expected outcomes of delegated tasks.

7. The seventh component was Succession Planning, whether the organisation compiles data of employees and job positions for TM and development, determines what performance is needed in the future by establishing future competency models for all job categories to evaluate the results of the TM program.

The second part of the questionnaire aimed to examine five components of the SERVQUAL model of SQ.

1. The first component was Responsiveness of employers, including prompt and timely service to clients, constructive handling of client complaints, willingness to defend and fight for client's rights, providing flexible service to match client needs, keeping the client informed as to when the service will be performed, and readiness to respond to client's questions.

2. The second component was Assurance, where the following characteristics were measured: politeness and courteousness of colleagues with clients, willingness to listen to client's point of view, ability to communicate in a language understandable to the client, providing complete and accurate information to the client within a reasonable time, ability to respond to client's queries, practising discretion and client safety and maintaining secure and accurate client's records.

3. The third component was Empathy, where the following were tested; colleagues were willing to help with the client's concerns and personal anxieties, responding sympathetically to the client's needs and respecting their privacy, respecting client's confidences and feelings, and giving individual attention to the client, and understanding client's needs.

4. The fourth component is Reliability, where the following were measured; ability to deliver appropriate, dependable and promised service, trustworthiness and inspiring confidence, and provide service accurately with minimum interruption.

5. The fifth component measured was Tangibles, whether the organisation has up-to-date, visually appealing physical facilities and modern equipment and presentable and neat employees' appearance.

\section{Test analysis}

In the test analysis to evaluate the quality of research, we used validity, which is about the accuracy of a measure and reliability, which is about the consistency of a measure (Neuman, 2014). Item reliability test reveals that for a small number of items, Cronbach's Alfa is above 0.9, which indicates high internal consistency. Cronbach's Alfa (Field, 2009) tests if multiplequestions under the Likert scale survey are reliable and accurately measure the variable of interest. Internal validity was used when a causal relationship between two variables is indicated. The correlation between items, in general, was above 0.6 (Pearson correlation coefficient). The results show a good correlation between the degree of each item and the overall scale, by which we can conclude that the survey is valid and reliable. 


\section{Results}

Descriptive statistics (Table 2) show that the mean value is above 3.40 in most components of $\mathrm{TM}$ and SQ components, which indicates that most respondents agree that all components are present in their law firms. The highest level of agreement in components of TM is seen in are Career Development, with a mean value of 3.83. The component of Succession Planning (mean 3.37), Talent Acquisition, and Retention (mean 3.37) have lower mean values, as respondents neither disagree nor agree with the statements. The highest mean value among SQ components was Tangibles, with a mean value of 3.97. The lowest mean value was for Responsiveness with a mean value of 3.79; however, we can still say that most respondents agree with the statement of TM components and SQ components.

Table 2: Descriptive statistics

\begin{tabular}{|l|l|l|l|}
\hline \multicolumn{2}{|l|}{ Talent Management } & & \\
\hline no. & Items & Mean & Std. Deviation \\
\hline 1 & Strategic employee planning & 3.4029 & 0.85414 \\
\hline 2 & Talent Acquisition and retention & 3.3786 & 0.76419 \\
\hline 3 & Performance Management & 3.4163 & 0.80355 \\
\hline 4 & Learning and Motivating & 3.6201 & 0.96611 \\
\hline 5 & Compensation & 3.6820 & 0.55841 \\
\hline 6 & Career Development & 3.8362 & 0.58968 \\
\hline 7 & Succession planning & 3.3762 & 0.76419 \\
\hline Service Quality & & \\
\hline 1 & Responsiveness & 3.7913 & 0.71063 \\
\hline 2 & Assurance & 3.8042 & 0.70439 \\
\hline 3 & Empathy & 3.8330 & 0.74210 \\
\hline 4 & Reliability & 3.8961 & 0.67592 \\
\hline 5 & Tangibles & 3.9750 & 0.63228 \\
\hline
\end{tabular}

Pearson's correlation coefficient shows a linear relationship between two variables. Table 3 presents the matrix of the correlation coefficients for variables of TM components and SQ components. Correlation is significant at the 0.01 level (1-tailed). The significant value indicates the probability of getting a correlation coefficient that big in a sample of 206 respondents if the null hypothesis were true. The output shows that variables are positively correlated. The strongest correlation between the TM component variable Learning and Motivating (TM) and variables of SQ components of Reliability $(\mathrm{r}=.700)$, Responsiveness $(\mathrm{r}=.691)$, Tangibles $(\mathrm{r}=686)$, and Empathy $(\mathrm{r}=.671)$, which are all significant at $\mathrm{p}<0.01$. Results indicate that the most critical TM component is Learning and Motivating, which has a strong relationship with SQ components.

Table 3: Correlation between the TM components and SQ components

\begin{tabular}{|l|l|l|l|l|l|l|}
\hline \multirow{2}{*}{ Talent management } & \multicolumn{5}{|c|}{ Service quality } & \multicolumn{1}{|c|}{} \\
\cline { 2 - 7 } & Responsiveness & Assurance & Empathy & Reliability & Tangible & $\begin{array}{l}\text { Service } \\
\text { Quality }\end{array}$ \\
\hline Strategic employee planning & $.637(* *)$ & $.466(* *)$ & $.613(* *)$ & $.631(* *)$ & $.607(* *)$ & $.622(* *)$ \\
\hline Talent acquisition and retention & $.537(* *)$ & $.420(* *)$ & $.523(* *)$ & $.506(* *)$ & $.468(* *)$ & $.520(* *)$ \\
\hline Performance management & $.601\left(^{* *}\right)$ & $.490(* *)$ & $.582(* *)$ & $.599(* *)$ & $.580(* *)$ & $.602(* *)$ \\
\hline Learning and Motivating & $.691(* *)$ & $.568(* *)$ & $.671(* *)$ & $.700(* *)$ & $.686(* *)$ & $.699(* *)$ \\
\hline Compensation & $.481\left(^{* *}\right)$ & $.475(* *)$ & $.493(* *)$ & $.498(* *)$ & $.514(* *)$ & $.520(* *)$ \\
\hline Career Development & $.450(* *)$ & $.335(* *)$ & $.484(* *)$ & $.459(* *)$ & $.454(* *)$ & $.460(* *)$ \\
\hline
\end{tabular}


\begin{tabular}{|l|l|l|l|l|l|l|} 
Succession Planning & $.683(* *)$ & $.536(* *)$ & $.650(* *)$ & $.677(* *)$ & $.643(* *)$ & $.673(* *)$ \\
\hline
\end{tabular}

** Corelation is significant at the 0.01 level

The multiple regression analysis predicts an outcome variable from several variables (Field, 2009). Results of multiple regression analysis for the components of TM and SQ components presented in Table 4 shows the coefficient of determination. $R^{2}$ (R Square) is a measure of the amount of variability in one variable shared by the other (Field, 2009). These values tell us how much the variability between the components is. In most of the cases, $\mathrm{R}^{2}$ is above 0.6 , except in the service components - Assurance. Suppose we convert the value into a percentage. In that case, we can say that TM components share $63.8 \%$ of the variability in responsiveness, 61.4 in Empathy, $63.1 \%$ in Reliability and $58.9 \%$ in Tangibles (all components of SQ). $\mathrm{R}^{2}$ also shows us the high correlation between these components. Multiple-regression indicates a significant relationship between some components of TM such as learning and motivating, succession planning and all components of SQ. Testing Hypothesis that All TM components have a significant relationship with SQ components. Our results from correlation and multiple regression analysis show that not all components of TM have a relationship with SQ components. For example, the TM component - shows that Learning and Motivating and Succession Planning has a significant relationship with service quality rather than career planning alone, suggesting that career prospects and development prospects may not fulfil employment needs as much as consistent encouragement, motivation and leadership mentoring components. 
Table 2: Multi-regression analysis for the components of TM on SQ.

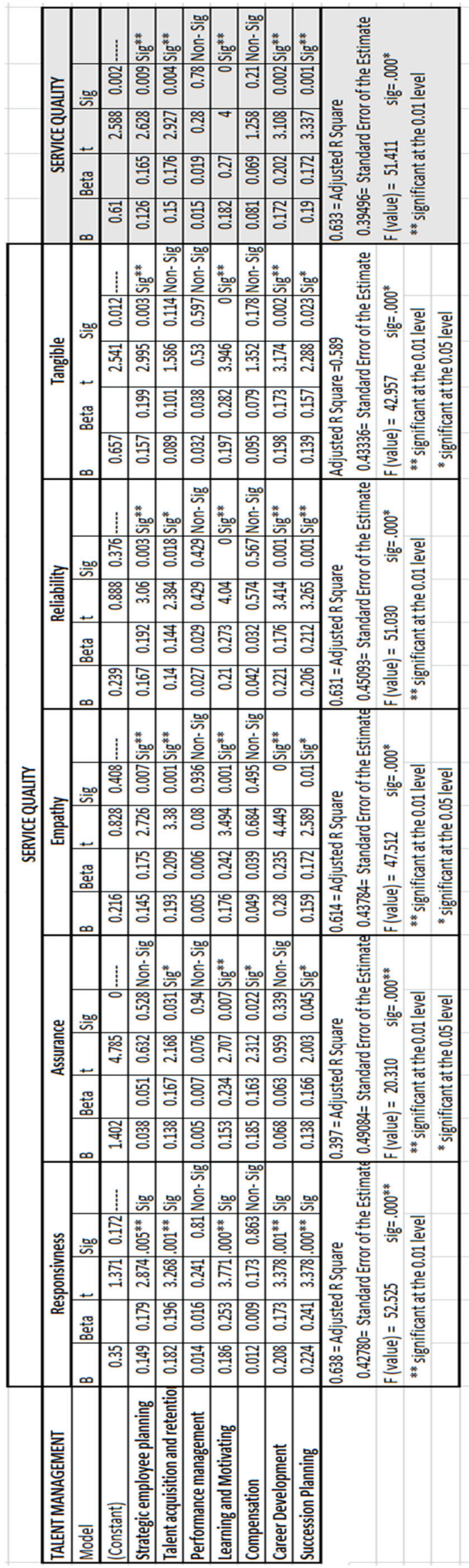


Figure 2 shows a significant relationship between TM components: Strategic Employee Planning, Talent Acquisition and Retention, Learning and Motivating, Career Development, Succession Planning and Responsiveness (a component of SQ). The possible reasons are that law firms consistently appoint highly talented employees who constructively handle client complaints and are ready to respond to the client's questions. There is no significant relationship between TM components: Performance Management, Compensation and SQ component Responsiveness. The organisation might not be fully aware of the level at which each team member performs; therefore, the employees might not provide prompt and timely service to clients. In addition, there is a significant relationship between Talent Acquisition and Retention, Learning and Motivating, Compensation, Succession Planning (components of TM) and Assurance (a component of SQ). The organisation possesses a genuine interest in fostering the learning and development of people; therefore, the employees communicate in a language that clients understand and know to answer clients' queries. Based on our results, there is no significant relationship between Strategic Employees Planning, Performance Management, Career Development (TM components) and Assurance (a component of SQ). Law firms do not adequately equip their team members with the necessary information and expected outcomes when delegating tasks; therefore, the employees do not always provide complete and accurate information to clients at the appropriate time. There is also a significant relationship between Strategic Employee Planning, Talent Acquisition and Retention, Learning and Motivating, Career Development, Succession Planning (TM components) and Empathy (a component of SQ). The organisation ensures that all team members have an understanding approach towards the personal and family needs; therefore, the employees are willing to help with client concerns. However, there is no significant relationship between Performance Management, Compensation (TM components) and Empathy (a component of SQ). The verbal or written recognition of employees' contributions does not indicate employees gaining client confidence and feelings of trust. There is a significant relationship between Strategic Employee Planning, Talent Acquisition and Retention, Learning and Motivating, Career Development, Succession Planning (TM components) and Reliability (a component of SQ). Law firms prioritise issues that concern employees' development and create the means to document competence and ensure that individuals are successful performers; therefore, they deliver the appropriate and dependable services as promised. There is no significant relationship between Performance Management, Compensation (TM components) and Reliability (a component of SQ).

Fair salary allocation and performance management are tangible incentives for employees to perform their job better, but not to provide service accurately with minimum interruption. Besides, there is a significant relationship between Strategic Employee Planning, Learning and Motivating, Career Development, Succession Planning (TM components) and the Tangibles (a component of SQ). Highly motivated staff usually pay close attention to appearance and dress code as part of their image and visual appeal of brochures and advertisements associated with services. Most law firms equip their team members with the necessary information; therefore, they focus on having a full range of up to date physical facilities and equipment as facilitation. However, there is no significant relationship between Talent Acquisition and Retention, Performance Management, Compensation (TM components) and the Tangibles (a component of SQ). The reason may be that fair salary allocation does not necessarily guarantee that the employees are neat and presentable in appearance. Moreover, while highly talented employees focus on maintaining a good client relationship and other core services, they do not pay particular attention to visually appealing services. This suggests that the hypothesis is only partially validated. 
Figure 2: Relationship of TM components with SQ components

TALENT MANAGEMENT

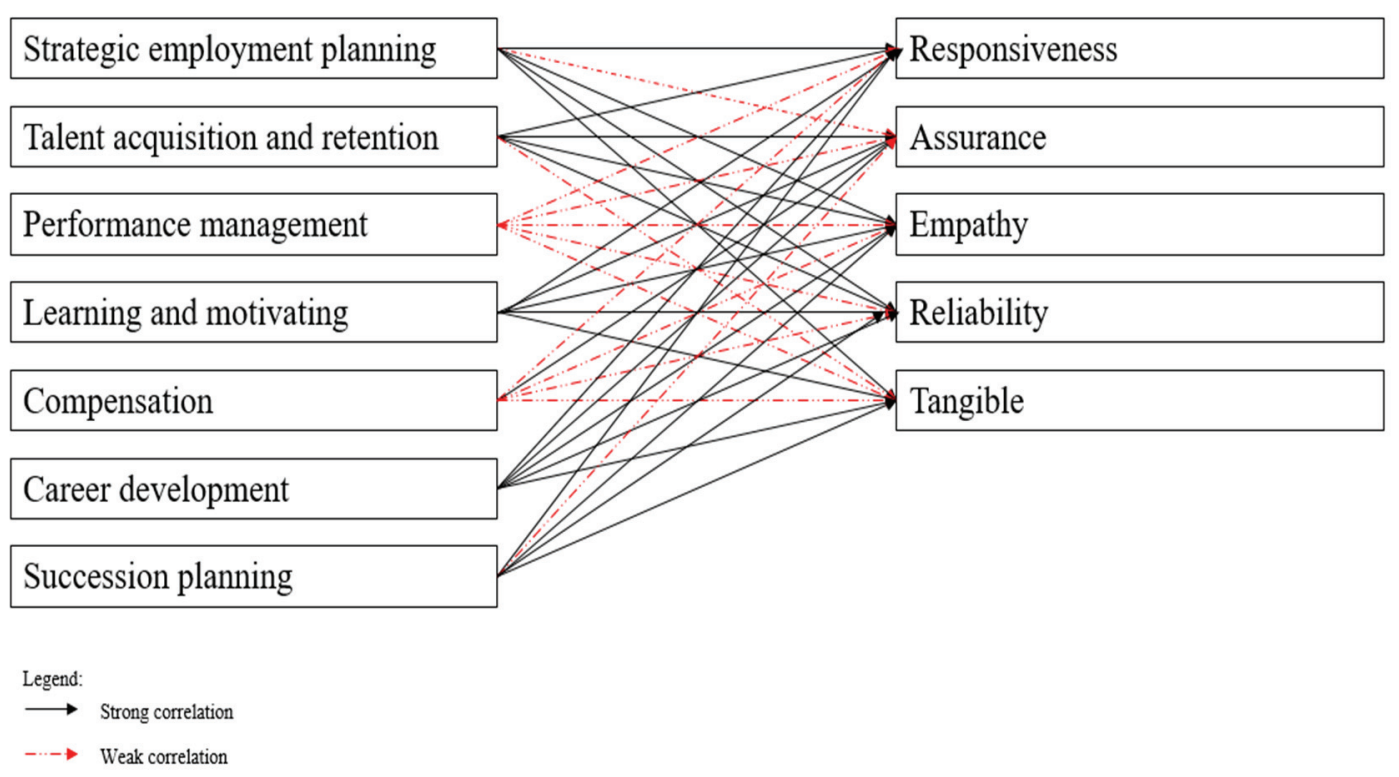

Further, our study shows that there is also a significant difference in succession planning and career development in terms of job type. In terms of business services, law firms actively create opportunities for team members to participate in challenging assignments and equip them with the necessary information whenever delegating tasks. While there is no significant difference for all components of TM in terms of gender, as the same policies and strategies influence both males and females since they work within the same environment, they are therefore both entitled to the same fringe benefits with and no specific privileges given to female more than the male.

Our results also show a significant difference in strategic employee planning, talent acquisition and retention, learning and motivating, performance management, and succession planning in terms of experience. A reasonable justification would be that as the employee's work experience increases, it becomes difficult to keep them motivated and work on their personal development as they consider themselves professionally experienced senior lawyers, and therefore rarely address their performance issues or exchange their experiences with them their colleagues.

\section{Conclusion}

Arbitration law firms in Egypt operate with high competition and lucrative environment, particularly since the 2011 revolutions due to the rising need to settle disputes relating to investment and commercial aspects. Arbitration is considered nowadays as a service-based industry, and arbitration law firms face many challenges in recruiting and retaining top talent and service the requirements of their clients. Client satisfaction, therefore, is critical to the success of the arbitration firm, and this depends on the commitment and performance of their employees. Various attempts at efficient TM have been used to have a significant relationship with SQ. This paper has attempted to evaluate the relationship of specific select components of TM on the SERVQUAL scale. The results revealed that not all the components of TM had an equal correlation to all components of SQ. Legal firms must constantly compile data on employees and job positions for consistent TM and development. Ongoing performance, assessment and effective planning of concurrent training programs will also improve SQ and enhance the overall effectiveness of TM. 
This study supports the need for a TM oriented approach by forecasting talent needs and defining different competency profiles, particularly for lawyers and other professionals, thereby encouraging talent contribution. An essential aspect of TM is to retain the existing talent within organisations. This might involve taking corrective action through flexible working hours, creating an employee value system and reviewing organisational policies repeatedly. Also, leadership cannot be neglected as it impacts employees confidence as well as skills. By developing an environment for planned and unplanned learning, the skill gaps evident in a globalised work environment can be decreased to maintain a competitive advantage for the organisation. Finally, it is essential to develop metrics that adequately measure the outcome of the HR development initiatives and enable the organisation to pinpoint which practices are working and how to plan and improve them for the best advantage.

This study is conceptual, and both an Egyptian and global perspective has been taken into consideration. However, this could be enhanced through further empirical research that might overcome the issue of generalisation. Additionally, the questionnaire technique was used to gather data, but more studies containing both qualitative and quantitative research methods could be conducted to achieve in-depth findings.

\section{References}

Almomani, G. (2017). Measuring Service Quality and Customers Satisfaction in the UK Mobile Telecommunications Market Using the SERVQUAL Instrument [Master Thesis in Business Administration, University of Lincoln]. file://C:/Users/Suzana\%20Kosir/Downloads/MeasuringServiceQuality.docx.pdf

Altman, M. A., \& Weil, R. I. (2007). How to manage your Law Office. Matthew Bender.

Arlen, J., \& Talley, E. L. (2008). Experimental Law and Economics (SSRN Scholarly Paper ID 1144086). Social Science Research Network. https://papers.ssrn.com/abstract=1144086

Babbie, E. (2008). The Basics of Social Research (4th Edition). Thomson Wadsworth.

Baldassari, P., \& Roux, J. D. (2017). Industry 4.0: Preparing for the future of work. People \& Strategy, 40(3), 2024.

Beechler, S., \& Woodward, I. C. (2009). The global “war for talent.” Journal of International Management, 15(3), 273-285.

Brown, P., Hesketh, A., \& Williams, S. (2004). The Mismanagement of Talent: Employability and Jobs in the Knowledge Economy. In The Mismanagement of Talent. Oxford University Press. https://www.oxfordscholarship.com/view/10.1093/acprof:oso/9780199269532.001.0001/acprof9780199269532

Bryman, A. (2012). Social Research Methods (4th Edition). Oxford University Press.

Carman, J. M. (1990). Consumer Perceptions Of Service Quality: An assessment of the SERVQUAL dimensions. Journal of Retailing, 66(1), 33-55.

Chaubey, D. S., \& Gupta, V. (2013). Talent management practices and its relationship with employees turnover: A study on employees working in insurance sector industries in Uttarakhand: An empirical study. Vedaang, $4(1), 62-72$.

Chiang, I.-C. A., Jhangiani, R. S., \& Price, P. C. (2015). Overview of Nonexperimental Research. In Research Methods in Psychology. BCcampus. https:/opentextbc.ca/researchmethods/chapter/overview-ofnonexperimental-research/

Christensen Hughes, J., \& Rog, E. (2008). Talent management: A strategy for improving employee recruitment, retention and engagement within hospitality organisations. International Journal of Contemporary Hospitality Management, 20(7), 743-757. https://doi.org/10.1108/09596110810899086

Collings, D. G., \& Mellahi, K. (2009). Strategic talent management: A review and research agenda. Human Resource Management Review, 19(4), 304-313. https://doi.org/10.1016/j.hrmr.2009.04.001

D'Annunzio-Green, N. (2008). Managing the talent management pipeline: Towards a greater understanding of senior managers' perspectives in the hospitality and tourism sector. International Journal of Contemporary Hospitality Management, 20(7), 807-819. https://doi.org/10.1108/09596110810897628

D'Annunzio-Green, N., \& Ramdhony, A. (2019). It's not what you do; it's the way that you do it: An exploratory study of talent management as an inherently motivational process in the hospitality sector. International Journal of Contemporary Hospitality Management, 31(10), 3992-4020. https://doi.org/10.1108/IJCHM11-2018-0905

Dhanabhakyam, M., \& Kokilambal, K. (2014). A study on existing talent management practice and its benefits across industries. International Journal of Research in Business Management, 2(7), 23-26. 
Elseidi, R. (2009). The Impact of Relationship Quality in Service Organisations on Customer Loyalty and Retention: An Application on Banking Sector [Doctor of Philosophy in Business Administration Thesis]. Ainshams University, Faculty of Commerce.

Elseleety, K. (2004). Measuring Medical Service Quality on Patience Satisfaction, An Empirical Study on Service Medical Centers in Qatar [Master Thesis in Business Administration]. Ainshams University, Faculty of Commerce.

Enquist, B., Edvardsson, B., \& Sebhatu, S. P. (2007). Values-based service quality for sustainable business. Journal of Service Theory and Practice, 17(4), 385-403. https://doi.org/10.1108/09604520710760535

Field, A. (2009). Discovering statistics using SPSS (3rd ed.). SAGE Publications Ltd.

Galanter, M., \& Palay, T. M. (1990). Why the Big Get Bigger: The Promotion-to-Partner Tournament and the Growth of Large Law Firms. Virginia Law Review, 76(4), 747-811. JSTOR. https://doi.org/10.2307/1073211

Gilson, R. J., \& Mnookin, R. H. (1989). Coming of Age in a Corporate Law Firm: The Economics of Associate Career Patterns. Stanford Law Review, 41(3), 567-595. JSTOR. https://doi.org/10.2307/1228880

Gioia, D. A., Schultz, M., \& Corley, K. G. (2000). Organisational Identity, Image, and Adaptive Instability. Academy of Management Review, 25(1), 63-81. https://doi.org/10.5465/amr.2000.2791603

Govaerts, N., Kyndt, E., Dochy, F., \& Baert, H. (2011). Influence of learning and working climate on the retention of talented employees. Journal of Workplace Learning, 23(1), 35-55. https://doi.org/10.1108/13665621111097245

Groysberg, B., \& Abrahams, R. (2006). Lift outs: How to acquire a high-functioning team. Harvard Business Review, 84(12), 133-141. https://doi.org/10.1108/hrmid.2007.04415cad.002

Harter, J., \& Adkins, A. (2015). Engaged Employees Less Likely to Have Health Problems [Report]. Gallup. http://www.gallup.com/poll/187865/engaged-employees-less-likely/health-problems.aspx

Holtom, B. C., Mitchell, T. R., Lee, T. W., \& Eberly, M. B. (2008). 5 Turnover and Retention Research: A Glance at the Past, a Closer Review of the Present, and a Venture into the Future. The Academy of Management Annals, 2(1), 231-274. https://doi.org/10.1080/19416520802211552

Irtaimeh, H. J., \& Al-Azzam, Z. F. (2016). Exploring the impact of talent management strategies and service quality on beneficiaries satisfaction in Jordan healthcare service: Provider point of view. International Journal of Management, 7(7), 22-38.

Järvi, K., \& Khoreva, V. (2020). The role of talent management in strategic renewal. Employee Relations: The International Journal, 42(1), 75-89. https://doi.org/10.1108/ER-02-2018-0064

Lavanya, P., \& Sumathi, N. (2019). A study on conceptual framework of talent management. Journal of the Gujarat Research Society, 21(16s), 589-593.

Lewis, R. E., \& Heckman, R. J. (2006). Talent management: A critical review. Human Resource Management Review, 16(2), 139-154. https://doi.org/10.1016/j.hrmr.2006.03.001

Lopes, S. A. (2016). High performers are not superheroes: Bridging exclusive and inclusive talent management approaches for law firm sustainability. International Journal of the Legal Profession, 23(2), 207-231. https://doi.org/10.1080/09695958.2016.1176924

Mayson, S. (2007). Law Firm Strategy: Competitive Advantage and Valuation. Oxford University Press.

Mehta, A. (2011). Human Capital Management: A Comprehensive Approach to Augment Organisational Performance. Review of Management, 1(2).

Moore, S. (2013). Understand the Components of Talent Management. BLOOM® Leadership Platform. https://leadersbloom.com/bloom-blog/2013/12/5/understand-the-components-of-talent-management

Neuman, W. L. (2014). Social Research Methods: Qualitative and Quantitative Approaches (Pearson New International Edition). Pearson.

Nithyapriya, B., \& Balaji, V. (2019). A Study on Factors Influencing Talent Management for Employee Retention of Small Scale Industries in Chennai. Our Heritage, 67(3), 153-164.

Oehley, A.-M. (2007). The development and evaluation of a partial talent management competency model [Thesis, Stellenbosch : University of Stellenbosch]. https://scholar.sun.ac.za:443/handle/10019.1/2110

Parasuraman, A., Zeithaml, V. A., \& Berry, L. L. (1988). SERVQUAL: A Multiple-Item Scale for Measuring Consumer Perceptions of Service Quality. Journal of Retailing, 64(1), 12-40.

Prowse, P., \& Prowse, J. (2009). The dilemma of performance appraisal. Measuring Business Excellence, 13(4), 69-77. https://doi.org/10.1108/13683040911006800

Quality in Legal Services: Report prepared by Vanilla Research for the Legal Services Consumer Panel (pp. 133). (2010). [Final]. Research. https://www.legalservicesconsumerpanel.org.uk/publications/research_and_reports/documents/VanillaRes earch_ConsumerResearch_QualityinLegalServices.pdf

Ramseook-Munhurrun, P., Lukea-Bhiwajee, S., \& Naidoo, P. (2010). Service quality in public service. International Journal of Management and Marketing Research, 3(1), 37-50. 
Sanchez, J. I., \& Levine, E. L. (2012). The Rise and Fall of Job Analysis and the Future of Work Analysis. Annual Review of Psychology, 63(1), 397-425. https://doi.org/10.1146/annurev-psych-120710-100401

Santhanalaxmi, K., \& Chandramohan, S. (2019). Succession Planning - An Intricate Phase in Talent Management System in Selected Organisations in Tamilnadu. International Journal of Advanced Science and Technology, 28(19), 967-975.

Shehata, F. (2006). Knowledge management as a strategy for improving the quality of medical services. Ainshams University, Faculty of Commerce.

Singh, K. (2007). Quantitative social research methods. Sage Publications India.

Stahl, G., Björkman, I., Farndale, E., Morris, S. S., Paauwe, J., Stiles, P., Trevor, J., \& Wright, P. (2012). Six principles of effective global talent management. Sloan Management Review, 53(2), 25-42.

Stangl, C. (2008). Inside the minds-Law Firm Human Resources. Aspatore Publishing.

Suseno, Y., \& Pinnington, A. H. (2017). The war for talent: Human capital challenges for professional service firms. Asia Pacific Business Review, 23(2), 205-229. https://doi.org/10.1080/13602381.2017.1287830

Taha, M. O. (2014). Egypt: Legal Framework for Arbitration. The Law Library of Congress, Global Legal Research Center. https://www.loc.gov/law/help/arbitration/egypt-legal-arbitration.pdf

The ALPMA-Annual Report 2014-2015 (pp. 1-22). (2015). [Annual]. Australasian Legal Practice Management Association.

Trigunait, R., \& Taruna. (2020). Innovative Practices of Talent Management in Digital Age: A Systematic Review. Journal of Engineering Sciences, 11(1), 7-15.

Uren, L. (2007). From talent compliance to talent commitment: Moving beyond the hype of talent management to realising the benefits. Strategic HR Review, 6(3), 32-35. https://doi.org/10.1108/14754390780000970

Whysall, Z., Owtram, M., \& Brittain, S. (2019). The new talent management challenges of Industry 4.0. Journal of Management Development, 38(2), 118-129. https://doi.org/10.1108/JMD-06-2018-0181

Zhang, X., Zhao, Y., Tang, X., Zhu, H., \& Xiong, H. (2020, January 7). Developing Fairness Rules for Talent Intelligence Management System. https://doi.org/10.24251/HICSS.2020.720 